\title{
DIGITAL HERITAGE AND SOCIETAL DEVELOPMENT
}

\author{
Edward Sankowski ${ }^{1 凶}$, Betty J. Harris² \\ ${ }^{1}$ College of Arts and Sciences, University of Oklahoma, 455 W. Lindsey St., Room 625, Norman, OK 73019 USA \\ ${ }^{2}$ College of Arts and Sciences, University of Oklahoma, 455 W. Lindsey St., Room 519, Norman, OK 73019 USA
}

\begin{abstract}
Aim of study

In their book Digital Heritage Karol Król and Józef Hernik have made a unique and major contribution to the history of digital technology, and, coupled with that, to identifying the significance of "digital heritage" for societal development, in particular in relation to developmental improvements in environmental processes. The aim of this article is to identify some main scientific, technological, and logical features of the book's account of what digital heritage is as part of environmental processes.
\end{abstract}

\begin{abstract}
Material and methods
The methodology used in this article is mainly examination of the text of the book, and study of that text's relationship with extra-textual societal phenomena as environmental processes.

\section{Results and conclusions}

Results. There are many logical inter-relations described in this paper between the Król/Hernik text and environmentally relevant sources in the development studies literature. There are also many logical inter-relations described in this paper between the Król/Hernik text and certain social science accounts of environmental processes and democracy (in relation to development or progress). Conclusions. This article concludes that the book deals with the history of technology, but that at the same time the book's text necessarily expresses concern with the present status of digital heritage, and particularly the role of digital heritage in future-centered societal development (in relation to environmental processes).
\end{abstract}

Keywords: ICT, history of computers, progress, environment, justice, democracy

\section{AIM OF STUDY}

While concerned about the future of digital technology, Król and Hernik devote their book to an account of the history of that technology. Why and how is there this coupling of past and future? The aim of the article is to show that in order to conduct the inquiry exemplified in the book, Król and Hernik must couple digital heritage with development. The aim of the paper is to show that (and how) this coupling is necessary in the Król/Hernik project.
Persons engaging in societal-development studies and knowledge-based interventions aiming at "development" look forward to the future. Often they hope for and actively seek "progress". But for that very reason, development studies and interventions must also enable looking back to the past, as expressed in cultural heritage. There is typically a need to come to collective understanding of, re-interpretation of, as well as a re-working (in the present) of the inheritance from the past, in order to move on into an improved future. In the "present" (which has vague boundaries)

『e-mail:esankowski@ou.edu 
people's experience of their environment is affected by factors not immediately present. Experience is conditioned by a sense of the past, and anticipation of the future. As to the latter, anthropologist Arjun Appadurai writes about "the future as cultural fact" (Appadurai, 2013). What is referred to here is a societal process, though it has its analogies in individuals. The book by Karol Król and Józef Hernik, Digital Heritage, is part of such a consideration of digital heritage (and more: advocacy in favor of enhanced societal attention to digital heritage). The societal processes for selecting and preserving digital heritage, the authors recognize, require thoughtful evaluation. This is to promote what is positive and avoid what is negative politically, economically and culturally. Thus respect for the past is meant to improve the future. Appadurai, for one, may highlight future-centeredness so much that he excessively de-emphasizes appreciative awareness of the past. Król and Hernik, however, have made a unique and major contribution to the history of digital technology coupled with development studies. That is noteworthy.

The authors of Digital Heritage write in their Foreword:

"(A) unified institutional archiving system raises concerns over the conscious and targeted selection of data to be preserved. A specific archivist behemoth could at some point turn into a tool of influence, and its decision-makers could 'erase the past' or designate 'only the right content' for archiving. All this raises the following questions: what deserves to be regarded as digital cultural heritage and, thus, to be preserved?"

One possible answer to the aforementioned question asked by Król and Hernik is rather general. Only a genuine democracy could legitimately establish, evaluate, and adjust the complex institutionalized practices (in universities, public archives, libraries, etc.) to make the decisions about selection of content and techniques that are necessary for the sake of worthy digital heritage. In this article, there is no attempt to give an account of democracy and its more specific institutions dedicated to digital heritage. Beyond the comparative generality of political philosophy, what is needed would be a more concrete comprehensive discussion (with many communities weighing in) of the varied specific institutions to carry out the tasks that need to be accomplished for the sake of a justifiable digital heritage (which would presumably contribute to positive societal development). One feature of engaged democratic discussion would be working out a justifiably proportionate influence for expertise and the general public. For example, archivists and librarians, or scientists and engineers, should presumably have an influential role in some decisions about digital heritage priorities. The general public, however, will have a legitimate role in deciding how much specialist expertise should decide. There is no algorithm for settling how this mixture should be constituted.

A comprehensive discussion about priorities in digital heritage preservation and dissemination is beyond the scope of this article, but it is also a necessity implied by the position of the book. One assumes that each society would need to define this democratic system according to its best traditions and current decisions. (That does not imply that all societies will get it right, according to their circumstances; think of the "Democratic" Republic of North Korea). Some accounts of societal development, notably that of Amartya Sen, designated below, do generally link development theory to democratic theory; but Sen does not address digital heritage. Addressing digital heritage is a logical necessity given Sen's own close linkage of democracy with public discussion and reasoning. Digital heritage is after all an important part of the informational background for contemporary democratic discussion and reasoning (Sen, 2017). In general, earlier accounts of "progress" such as those in Dewey (Dewey, 1916) are mutually supportive with Sen's account of development and progress, which links development/progress with democracy. Dewey adds some provocative comments on the scope of "environment".

A helpful contemporary discussion of democracy can also be found in Philip Pettit's Just Freedom (2014), especially Chapter 5, Freedom and Democracy. Pettit considers various types of arrangements that could realistically allow for democratic popular influence on government and other institutions. Pettit does not discuss digital heritage, but his ideas could be adapted and used to guide invention of democratic decision-making practices about digital heritage.

A point of clarification is desirable here. "Digital heritage" is a phrase that may be used in a logically affirmative sense, so that what is heritage is necessarily worthy. However, we need to understand that in anoth- 
er linguistic usage, negative "digital heritage" (e.g., an Orwellian distortion of history) could be a possibility. This ambiguity in the phrase "digital heritage" need not be disturbing, so long as context provides the opportunity for clarification, evaluation, and pragmatic improvements.

\section{METHODS-DISCUSSION: THREE SOURCES ABOUT DEVELOPMENT, USEFUL IN INTERPRETING THE KRÓL/HERNIK TEXT}

Among many general accounts of development, three authors stand out for purposes of this article. (They are relevant to elucidating the implications of the book Digital Heritage). There is the collective authorship of the 1987 Brundtland Report, Our Common Future, (co-ordinated by Gro Harlem Brundtland), and successor value systems indebted to Brundtland; there is the classic, Development as Freedom, 1999, by Amartya Sen, which is not aimed to explicate sustainable development as such; and there is the work by Joseph Stiglitz and Bruce Greenwald, in Creating a Learning Society-A New Approach to Growth, Development, and Social Progress, 2015 (again, not targeting sustainable development as such). Of these three sources of ideas, the Brundtland collectivity is most attuned to environmental (as well as justice) issues. "Stiglitz", however, (as this article often refers to Stiglitz and Greenwald), seems the most promising of these resources for purposes of further commentary on the Król and Hernik book. One aspect of development is scientific and technological progress, including advances in digital technology. An emphasis on science and technology (and learning or innovation generally) is prominent in Stiglitz. However, he does not much - if at all - directly address digital heritage. But it is noteworthy that Stiglitz is very interested in the significance of information in social practices. Of these three resources, the Brundtland Report is most explicitly about environmental processes, although the other two resources also pay attention to environmental issues.

Technological progress might be said to have at least two features. There are gains in the capacities of a technology as a tool (not predominantly regarding the specific areas of its use). And there are advances in inventing or discovering features of the range of domains in which a technology can gainfully function (e.g., the use of Digital Vellum, discussed by Król and Hernik). To pursue research on digital heritage in this second sense is to innovate in grasping the range of domains of functioning of digital technology (e.g., its uses in representing and disseminating information, including rich aesthetic and other perceptions of historical artifacts and natural objects).

The interdisciplinary and multidisciplinary implications of the Król and Hernik book are especially notable. Besides computer science and development studies, among other academic and learned-professional areas in which their work is instructively and pragmatically relevant, are anthropology, archaeology, history, urban and rural planning, architecture (including landscape architecture), many engineering disciplines, the arts ("fine" and popular), philosophy, psychology, many other social sciences, education, business, law, and so on. This interdisciplinarity and multidisciplinarity tends to encourage considerable methodological variety (in addition to the focus on textual and extra-textual matters assigned primacy in this paper).

Digital Heritage contains a great deal of useful history and "normative" commentary about ("ICT"type: Information and Communication Technology) technological development. Arguably, such content in the book can be constructive in furthering more innovation and learning (concepts referring to processes which Stiglitz depicts as central to growth, development, and social progress). An advantage of Król and Hernik over Stiglitz is that they, more than he, are well aware that there are central normative questions about values that are as yet unanswered but that are about matters that will influence how digital technology could be genuinely progressive, and about how to avoid an Orwellian control of the past by selective preservation and deleting of features of heritage, to avoid uses of technology going wrong. Stiglitz seems to think that the key ingredients of how to do this are available from the European Enlightenment, the US Declaration of Independence, and related US-focused values. However, the historical and contemporary experience of the Central/Eastern Europeans seems to make them more thoughtfully concerned about further possible problems, transcending the Stiglitz value scheme, for societal development. 


\section{RESULTS-DISCUSSION: DIGITAL HERITAGE, DEVELOPMENT, AND ENVIRONMENTS}

Digital technology could be conceived as constituting as well as enabling the extension of the environment(s) of humans. To the extent that old hardware and its functioning (including operation of accompanying software) come to attract attention, and as efforts at preservation of the past of computer technology evolve, the environment of any human group (e.g., all human-kind, or Poland's population, or that of the US) evolves, growing larger (often) and more multi-faceted. Of the three authors explicitly mentioned above as researching development, Brundtland et al. are most attentive to explicitly environmental concerns. Also, Brundtland emphasizes the role of worldwide provision of technology for the sake of sustainable development. This applies particularly for less than optimally developed societies. Though Brundtland does not stress it or even mention it, the technology for digital heritage (and associated management improvements) is part of this. There is little or no discussion in Our Common Future specifically about ICT. (There is an updated account of sustainable development in Sachs, 2015, which does comment euphorically on the importance of the information technology revolution). However, in the Król and Hernik book, there are sometimes references to sustainable development, a value classically defined (for a while, as history has unfolded) in the Brundtland Report since 1987. How might digital heritage impact the concept of the environment, whether in the Brundtland sense or other senses?

First, the software and hardware that are constitutive elements in digital technology can come to be highlighted for individual or group attention. Thus, these objects can become part of the learning environment for various persons. If old physical information technology hardware becomes part of a museum display, for example, this changes the potential surroundings of persons, i.e., changes their environment, actually or potentially. Information about the historical and socio-economic surroundings of the hardware (or software) may be included in the changes to the learning environment. Król and Hernik do helpfully refer to museological dimensions of dissemination of cultural heritage. "Learning environments" are not, it is maintained here, merely related metaphorically or by a pun to more common talk about the environment today. Learning environments, including those impacted by ICT, are a genuine, major part of people's environment(s). This outlook is supported, inter alia, by the (pre-digital era) views of the US social and educational theorist, John Dewey. Dewey writes, "The words 'environment,' 'medium' denote something more than surroundings which encompass the individual. They denote the specific continuity of the surroundings with his own active tendencies. (...) (S) ome things which are remote in space and time from a living creature, especially a human creature, may form his environment even more truly than some of the things close to him. The things with which a man varies are his genuine environment. (...) The environment of an antiquarian, as an antiquarian, consists of the remote epoch of human life with which he is concerned, and the relics, inscriptions, etc., by which he establishes connections with that period." (Dewey, 1916) And further: "The environment consists in the sum total of the conditions which are concerned in the execution of the activity characteristic of a living being. The social environment consists of all the activities of fellow beings that are bound up in the carrying on of the activities of any one of its members." (Dewey, 1916)

Second, in a more aggressively creative mode about the evolving environment, digital technology enables the representation of and increased elaboration on worthwhile artifacts and "natural" objects (by uses of the growing potential powers of digital technology). The Król and Hernik book, of course, refers to both of the two aspects just mentioned, i.e., two aspects of research on digital heritage and environments. This article regards this as part of environmental commentary.

\section{RESULTS-DISCUSSION: DEMOCRATIC AND JUSTICE -FOCUSED ACCOUNTS OF DIGITAL HERITAGE AND DEVELOPMENT}

Beyond environmental-amplifying (creating or recognizing new possibilities for environments, or for "the environment") functions of innovations in digital technology as regards cultural heritage, all three of the intellectual resources on development mentioned above 
(Brundtland, Sen, Stiglitz) are concerned about distributive-justice dimensions (or "equitable" dimensions) of development. Perhaps this is more pronounced in the Brundtland Report and in Sen than in Stiglitz. Król and Hernik, too, are concerned, e.g., about expanding popular access to cultural heritage through innovative uses of digital technology. For example, they discuss inequitable limitations sometimes imposed historically on development of Polish digital technology, limitations because of Soviet political and economic policy. They also discuss economic and other societal conditions that have limited public (domestic or worldwide) access to valuable elements of cultural heritage as well as digital technology.

It was noted above that, necessarily, decisions about what in cultural digital heritage we ought to preserve, and how, and its accessibility, involve values, including ethical-political, economic, and cultural values. Digital technology, like all technology, is part of society. Król and Hernik recognize that related value questions remain incompletely answered, but must be addressed in approaching digital heritage.

Consider the closing sentences in the Król and Hernik volume, and other passages scattered throughout the book:

"The selection of what will be classified as significant cultural heritage to be preserved can be more problematic than both the archiving itself and ensuring the accessibility of digital collections. Cultural heritage is what modern society chooses from the past to pass on to future generations. Many digital collections comprise subjectively selected games and programs which, as archivists believe, deserve to be regarded as 'breakthrough' in a particular era. Who controls the past, controls the future. Who controls the present, controls the past (George Orwell, 'Nineteen Eighty-Four', 1949). Lyons ... drew attention to the questions which, according to the archivist community, are currently more burning than ... bit loss, namely: what deserves to be regarded as digital cultural heritage and, thus, to be preserved? Who is competent to decide what will be archived and based on what criteria? These questions have not been clearly answered to this day."

This only makes the area of investigation of digital heritage more important and interesting, as well as more challenging. Among the three volumes referred to as resources at the beginning of this essay, Amartya Sen's classic Development as Freedom (and other writings and further recorded communications of his) constitutes the most sophisticated book-length treat- ment of normative ethics and democratic theory in relation to societal development. However, he has little to say about digital technology. Nonetheless, a natural extension of Sen's emphasis on democracy and public discussion would be its continuation with a detailed account of the societal role of digital heritage and its impact on the future. Such an extension could plausibly be linked with some of the key concerns of Król and Hernik about values as well as about more technical history and contemporary challenges concerning digital heritage.

It might be added here that issues regarding digital heritage and surveillance, or privacy protection rights, can be added to the 1984 concerns that are mentioned by Król and Hernik. A popularized discussion by Andreas Weigend, (Weigend, 2017) illustrates this with many examples, taken primarily from US and Western European situations.

\section{CONCLUSIONS}

What conclusions can we draw about what are some major research functions that the Król and Hernik text can serve?

(1) It obviously includes a lot of historical facts (data), details, conceptual tools, and references to literature useful for the study of digital heritage. To say that this aspect is comparatively non-interpretive is consistent with affirming (as this article does) that the book offers the facts embedded in a valuable complex narrative of the development of digital heritage as an area of attention. For instance, the book gathers references to a variety of types of scholarship and other writings about digital heritage. Thus, the book can provide helpful (relatively "non-directive") clues and resources for researchers pursuing investigations with a wide range of research motivations, focused on many topics. Topics such as computer games, popular culture, the history of the computer mouse, connections of digitization with both government actions and commercial projects, the Cold War and its aftermath, consumer behavior, hands-on technical methodologies (such as surveying buildings for generating digitized records or furthering creative design work), etc., are among the many ingredients in this volume (or more appropriately, the digitized text correlative to this volume). 
(2) Somewhat more specifically, and more in a mode of societal interpretation, this book often connects technical details and trends with a wider societal context within which digital heritage has become more and more of a factor in development. In this respect, the text contains many comparatively directive interpretive suggestions for exploration of further connections of this sort.

(3) Much but not all of the book concentrates on developments specifically in Poland, with some attention to symbiotic relationships of Poland and other nation-states or more hard-to-define influential governance entities (such as the USSR and the former Eastern bloc, with its Warsaw Pact, "Western" universities and corporations, etc.). Thus the book is useful as a resource on aspects of the history and anthropology of Poland (and its international interactions) in the past (pre-1989 and post-1989). In such history and anthropology, researchers can begin with a specific cultural focus (Poland) and then connect this focus with comparative subject matter also studying much of the rest of the world.

(4) However, in addition to the emphasis on past Polish issues, the book can gainfully extend the study of digital heritage into a societal-developmental present-defined and future-directed area for academic and real-world deliberation and decision-making, with environmental implications. It is possible that digital heritage, in the present and future, will be an area for Poland to further extend its political economy and culture into mutually beneficial relations with non-Polish entities. Thus, digital heritage can become a way to connect national heritage with world or global heritage, and vice versa. This has potential for political and economic alliances, exchange of Polish and other-than-Polish cultural artifacts, tourism, etc.

The book can plausibly lead to increased research activity about digital heritage and societal development as an interdisciplinary and multidisciplinary area, as well as a locus for symbiotic connections between academic and extra-academic organizations.

(5) The Stiglitz work that is referred to herein makes heavy use of the idea of the economic developmental importance of learning environments, and scientific and technological innovations (aspects of "learning" in a society, in the Stiglitz vocabulary).
Among the many apropos discussions in Stiglitz (2015), there are remarks about certain positive developments in South Korea that resulted to a notable degree because of an emphasis on computer-related manufacturing, and other scientific and technological innovations, including smartphones and other highend ICT. South Korea's shift toward semiconductor manufacture was part of its once new emphasis on scientific and technological factors in development, rather than on gains from traditional agricultural practices. Stiglitz and Greenwald write, "Korea did not have a comparative advantage in producing semiconductors when it embarked on its transition. Its static comparative advantage was in the production of rice. Had it followed its static comparative advantage ... then that might still be its comparative advantage; it might be the best rice grower in the world, but it would still be poor." (2015)

There is no claim by any means here that societal development in Poland can be modelled on any of the particular examples that Stiglitz and Greenwald discuss (including South Korea). However, it is worth considering the possibility that investments in research on digital heritage might be a productive part of a positive developmental strategy in Poland. Such a strategy could be consistent with maintenance of crucial cultural traditions, such as modest-sized private agricultural and community life, rural and forest-defined life-styles, etc. Indeed, an emphasis on heritage suggests the possibility of maintaining what many Poles would cherish (despite urbanization trends). All that is, at present, relatively speculative. Moreover, there might be lessons from Poland that could be instructive for other parts of the world. That is also speculative.

What contribution might emerge from the Król and Hernik book to debates about a development strategy for Poland, partially based on digital heritage research? Possibly, a review of the history that Król and Hernik present might generate helpful insights for planning about future development, for example, in Poland, but also in the other Visograd countries, or in more far-flung regions. A forthcoming edited volume about cultural heritage and land-use issues may be relevant here. That volume links research on cultural heritage with land-use issues in Poland, Czechia, Slovakia, Italy, China, South Africa, and the US. A digi- 
tal heritage dimension could be added to the various studies in that volume.

It is worth mentioning that at present (in March, 2020) there is a major global crisis related to the coronavirus pandemic, as this article is being composed. This is currently forcing migration of much of higher educational teaching efforts online. We can expect an enormous number of questions to arise, for current practices as well as for future historiography, about the strategic or tactical issues concerning digital heritage materials (in this case, educational) generated by these events.

(6) Even apart from the current coronavirus crisis, online and distance education was already becoming a major feature of educational environments (including higher education). It is likely that the coronavirus crisis will hasten this already previously major phenomenon. And we could confidently anticipate that educationally-centered materials will pose many questions about preservation of digital heritage. Educational theorists will have a lot of research to add to the already voluminous body of work about digitally based education. Examining that added research with Król's and Hernik's approach in mind promises to be fruitful.

(7) The online/print-on-paper journal, Formatio Circumiectus (Environmental Processes)-Acta Scientiarum Polonorum is itself a part of digital heritage (Polish and international) which publicizes research that is both fact and data based, and potentially useful for environmentally focused developmental planning. This journal self-declares (in a statement about its aim and scope) as a collection of "papers concerning environmental planning understood as various forms of human activity in the environment." Thus this journal has a logic about its mission that to some extent resembles some basic features of the Król and Hernik book (2020), in including data-centered scientific research about the past and present, often linked with potential future-oriented environmentally developmental research. Papers in the journal could be identified to confirm this similarity to the Król and Hernik book (2020). One example is the following paper, Pawlat-Zawrzykraj, A., and Podawca, K. (2018). The authors of this 2018 paper use data (including computerized data, part of "digital heritage") to support their claims (published online, of course) about improvements in environmentally relevant planning concerning land use.

\section{REFERENCES}

Appadurai, A. (2013). The Future as Cultural Fact. London: Verso.

Dewey, J. (2016). Democracy and Education. New York: Macmillan.

Król, K, Hernik, J. (2020). Digital Heritage - Reflection of Our Activities. Wydawnictwo Uniwersytetu Rolniczego w Krakowie, ISBN 978-83-64758-98-0.

Pawlat-Zawrzykraj and A. Podawca, K., (2018). Maintaining Natural Connectivity of National and Regional Importance in Terms of Local Land-Use Planning and Management-The Case of Wieliszew Municipality. Acta Sci. Pol. Formatio Circumiectus 17(4), 35-44

Pettit, P. (2014). Just Freedom-A Moral Compass for a Complex World. New York: Norton. See especially, Chapter 5, Freedom and Democracy, 109-149.

Prus B., Król K., Gawroński K., Sankowski E., Hernik J. (2020) From Classic (Analogue) to Digital Forms of Cultural Heritage Protection in Poland. In: Kremers H. (ed.) Digital Cultural Heritage. Springer. DOI https:// doi.org/10.1007/978-3-030-15200-0_17

Sachs, J.D. (2015). The Age of Sustainable Development. New York: Columbia University Press.

Sankowski, E., Harris, B.J., Hernik, J. (2016). Some Problems and Possibilities for Sustainable Development. Krakow: Publishing House of the University of Agriculture in Krakow.

Sen, A. (1999). Development as Freedom. New York: Knopf.

Sen, A. (2017). Collective Choice and Social Welfare. Cambridge, Massachusetts: Harvard University Press. See in particular, "Democracy and Public Engagement", 395-408.

Stiglitz, J.E., and Greenwald, B.C. (2015). Creating a Learning Society-A New Approach to Growth, Development, and Social Progress. Reader's Edition. New York: Columbia University Press.

Weigend, A. (2017). Data for the People-How to Make Our Post-Privacy Economy Work for You. New York: Basic Books.

World Commission on Environment and Development (1987). Our Common Future. (Also known as "The Brundtland Report"). Oxford: Oxford University Press. 


\section{DZIEDZICTWO CYFROWE I ROZWÓJ SPOŁECZNY}

\section{ABSTRAKT}

\section{Cel badań}

W swojej książce Cyfrowe dziedzictwo Karol Król i Józef Hernik wnieśli wyjątkowy, znaczący wkład w historię technologii cyfrowej, zarazem ukazując znaczenie „dziedzictwa cyfrowego” dla rozwoju społecznego, w szczególności w odniesieniu do usprawnienia rozwojowych procesów środowiskowych. Celem niniejszego artykułu jest przedstawienie niektórych spośród najważniejszych naukowych, technologicznych i logicznych elementów wspomnianej monografii - dotyczących dziedzictwa cyfrowego w kontekście procesów środowiskowych.

\section{Materiat i metody}

Metody. Metodologia zastosowana w tym artykule polega głównie na omawianiu tekstu książki i badaniu jego związków z pozatekstowymi zjawiskami społecznymi jako procesami środowiskowymi.

\section{Wyniki i wnioski}

Wyniki. Artykuł przedstawia liczne związki logiczne pomiędzy tekstem Króla/Hernika a informacjami dotyczącymi aspektów środowiskowych w źródłach poświęconych badaniom rozwoju, a także pomiędzy tekstem Króla/Hernika a niektórymi relacjami nauk społecznych dotyczącymi procesów środowiskowych i demokracji (w kontekście rozwoju bądź postępu).

Wnioski. W artykule stwierdza się, że książka opisuje historię technologii, ale jednocześnie jej tekst wyraża zaniepokojenie obecnym stanem dziedzictwa cyfrowego, a zwłaszcza jego rolą w rozwoju społecznym skoncentrowanym na przyszłości (w odniesieniu do procesów środowiskowych).

Słowa kluczowe: ICT, historia komputerów, postęp, środowisko, sprawiedliwość, demokracja 